\title{
The Nonproliferation Review
}

\section{Turkey's quest for peaceful nuclear power}

\section{Mustafa Kibaroglu}

To cite this article: Mustafa Kibaroglu (1997) Turkey's quest for peaceful nuclear power, The Nonproliferation Review, 4:3, 33-44, DOI: 10.1080/10736709708436677

To link to this article: https://doi.org/10.1080/10736709708436677

\section{曲 Published online: 05 Feb 2008.}

Submit your article to this journal $2 \pi$

LII Article views: 174

4 Citing articles: 4 View citing articles 준 


\title{
TURKEY'S QUEST FOR PEACEFUL NUCLEAR POWER
}

\author{
by Mustafa Kibaroglu ${ }^{1}$
}

Mustafa Kibaroglu received his Ph.D. in International Relations from Bilkent University in Ankara, Turkey, in July 1996. He has subsequently held an International Atomic Energy Agency fellowship at the Programme for Promoting Nuclear Non-Proliferation (PPNN) of the Mountbatten Centre for International Studies in Southampton, England, and a postdoctoral fellowship at the Center for Nonproliferation Studies of the Monterey Institute of International Studies.

$\Omega$ hirty years ago, Turkey launched the first feasibility studies for a nuclear power plant with a view to benefit from peaceful exploitation of nuclear energy. However, neither that nor subsequent attempts have come to fruition for a variety of reasons, ranging in part from a lack of a welldefined national strategy in this area to domestic political problems. But the most significant hurdle has been the Western countries' fear of a retransfer of nuclear material and technology from Turkey to third parties. Specifically, the United States has feared a Turkish-Pakistani connection. India and Greece have further fueled these fears by disseminating rumors about such a connection. As a result, the United States has put pressure on supplier countries and firms to deny transfers of nuclear reactors and related technology to Turkey.
Notwithstanding the allegations of a Pakistani connection, Turkey became a state party to the Treaty on the Non-Proliferation of Nuclear Weapons (NPT) by signing it on January 29,1969 , and ratifying it on April 17, 1980. Turkey concluded a "full-scope" safeguards agreement with the International Atomic Energy Agency (IAEA) in 1982. In accordance with its foreign and security policy, ${ }^{2}$ Turkey has also become a state party to international agreements that seek to prevent the spread of all sorts of weapons of mass destruction, such as the Biological Weapons Convention of 1972 and the Chemical Weapons Convention of 1993. At the NPT Review and Extension Conference, held in New York in April/May 1995, Turkey gave its full support to the "indefinite and unconditional extension" of the Treaty. Turkey also used its influence on the Turkic republics of Central Asia and the Caucasus to induce them to behave the same way. More recently, Turkey assumed a full member status in the Conference on Disarmament (CD) in Geneva after a long period of attending the meetings as an observer. As a country that never sought to acquire weapons of mass destruction, Turkey has endorsed efforts to strengthen the nuclear nonproliferation regime and the verification mechanisms of the IAEA. Therefore, Turkey pays close attention to the proceedings of the IAEA's "Programme 93+2," in its efforts to make IAEA safeguards inspections more comprehensive. Above all, Turkey has been a "staunch ally" of the North Atlantic Treaty Organization (NATO) countries since 1952 and has carried a significant portion of the burden of defending the West against the Soviet Union. ${ }^{3}$ Thus, the opposition of the United States (as well as of Canada and Germany) to Turkey's attempts to benefit from peaceful 
uses of nuclear energy is difficult to understand.

Turkey is a rapidly growing country, and its present and forecasted energy needs extend well beyond its currently installed power generating capacity. Despite outstanding success in completing power generation projects in the 1970s and 1980s, Turkey now suffers from frequent power outages that have caused serious losses, especially to its industrial output. Since the early 1990 s, Turkey has not been able to finance dozens of projects of different sizes that would further exploit its power generating potential. But these efforts are likely only to postpone the energy crisis it will soon face unless it resorts to sources of energy other than those traditionally exploited thus far. That is, Turkey's hydropower and thermal energy sources will not be sufficient to meet the steady increase in its energy requirements in the decades to come. Currently, Turkey has a population of approximately 65 million, and an estimated population of 85 million in 2010.4 Turkey has insignificant reserves of oil and natural gas and thus is dependent on other countries. But Turkey has other sources of energy, such as hydro power, coal, geothermal, wind, and solar, as well as considerable reserves of uranium and thorium. Of all these, however, only hydro power and coal have been properly exploited over the past few decades. ${ }^{5}$ Research indicates that demand will again exceed domestic supply in the early 2000 s. ${ }^{6}$ Consequently, resorting to peaceful exploitation of nuclear power is currently being discussed and will continue to come to the fore as an alternative strategy for Turkey to diversify its primary sources of energy.
This article will explore how and why Turkey has not succeeded in installing a substantial nuclear power infrastructure, despite serious efforts over the last three decades. It will discuss the reasons behind the failure of past attempts and make recommendations for guiding further Turkish efforts to acquire nuclear power and technology. It argues that the fear of Western supplier countries of alleged Pakistani connections has had a negative effect on Turkey's initiatives in the past. Thus, it makes the case that Turkey's current tender for nuclear reactors could be a timely opportunity for both the West and Turkey to mend these relations. ${ }^{8}$ Finally, it concludes that if Western countries are to be expected to assign a higher priority to Turkey's energy requirements, Turkey must be willing to take steps toward greater transparency in its nuclear-related transactions and activities.

\section{TURKEY'S ATTEMPTS TO EXPLOIT NUCLEAR ENERGY \& ALLEGATIONS OF AN ILLICIT PAKISTANI CONNECTION}

Turkey's attempts to exploit peaceful nuclear power have been shadowed by allegations of its illicit cooperation with Pakistan. Thus, these two developments will be discussed together in chronological order. Turkey began thinking about the development of peaceful nuclear energy after Eisenhower's "Atoms for Peace" initiative speech before the U.N. General Assembly in 1953, and the Geneva Conference of 1955. Many of the secrets in the nuclear field were disclosed during the conference, particularly by the United States and the Soviet Union, to al- low more countries to exploit nuclear energy for peaceful purposes. In 1956, the Turkish Atomic Energy Commission (TAEC) was established under the auspices of the Prime Ministry to coordinate efforts to build nuclear research and training centers, and to issue licenses for nuclear power plants.

\section{First Phase: The 1960s \& 1970s}

In 1961, Cekmece Nuclear Research and Training Center (CNRTC), the first nuclear research and training center in Turkey, was established. That was followed by the installation of a one megawatt thermal (MWth) pool-type research reactor TR-1 in CNRTC a year later. ${ }^{9}$ Then, in 1966, Ankara Nuclear Research and Training Center (ANRTC) was established in the environs of the capital, as the second major branch of TAEC, for carrying out "fundamental and applied research to use nuclear energy and technology for the benefit of the country and to support the national development."10 With a view to exploit Turkey's natural uranium reserves, the first feasibility studies for the construction of a 300 to 400 megawatt electric (MWe) pressurized heavy water reactor (PHWR) were launched in 1967 in order to start generating electricity by the year 1977. However, domestic economic and political developments halted that initiative. ${ }^{11}$ In a second attempt, the Nuclear Power Plants (NPP) division of the Turkish Electricity Authority (TEK) - which had undergone a reorganization in 1970carried out comprehensive feasibility, site selection, and bid specification studies between 1972 and 1974 for a $600 \mathrm{MWe}$ nuclear power plant. ${ }^{12}$ Surveys for the selection of 
a nuclear site were conducted throughout Turkey. Due to its stable seismic conditions, Akkuyu Bay on the Mediterranean coast-about 43 kilometers southwest of Silifke-was selected. ${ }^{13}$. Next, TAEC issued a license in 1976 for the site selected by TEK. After the preparation of the necessary paperwork for bidding, with the assistance of a consortium of one French and three Swiss firms, negotiations on the construction of a 600 MWe nuclear power plant, fuel services, and the financing of the investment were begun in 1977 with two half-state-owned Swedish firms, namely Asea-Atom and StalLaval. ${ }^{14}$ These negotiations were interrupted by the military coup in Turkey in $1980 .^{15}$

\section{Second Phase: The 1980s}

In 1979, the 250 kilowatts thermal (kWth) Triga Mark II research reactor started operations, and in 1981, the TR-1 research reactor, which was shut down in 1977, was replaced by a five MWth pool-type research reactor TR-2. These two research and training reactors are the only reactors currently operating in Turkey. In early 1980 , a site selection survey for a second nuclear power plant began. Then, Inceburun, the northernmost point of Turkey in the central Black Sea region located some 25 kilometers west of Sinop, was selected by the NPP division of TEK. The early 1980 s also marked the beginning of allegations of illicit cooperation between Turkey and $\mathrm{Pa}$ kistan. In 1981, the United States expressed concerns about a TurkishPakistani alliance on the grounds of alleged shipments from Turkey to Pakistan of strategic material with potential nuclear weapons implications. The United States feared that
Turkey's help would enable Pakistan go ahead with its quest for uranium enrichment technology. It was reported that Robert Strausz-Hupe, the U.S. ambassador to Ankara, discussed the matter with Turkish Minister of Foreign Affairs Ilter Turkmen. Ambassador Omer Ersun, who was then-Chief of the Policy Planning Staff at the Turkish Ministry of Foreign Affairs, confirmed that the U.S. administration raised concerns about the $\$ 30,000$ shipment of inverters to Pakistan by a Turkish textile firm. Ambassador Ersun stated that neither the Turkish Ministry of Foreign Affairs nor the private textile manufacturer had any specific knowledge that the inverters were intended for Pakistan's uranium enrichment program. ${ }^{16}$

Allegations of an illicit Turkish-Pakistani connection indeed owe much to the unique characteristic of relations between the two countries. For almost any Turkish citizen, Pakistan is believed to be the one and only really friendly country to Turkey. ${ }^{17}$ Revolutionary thoughts and the principles of Mustafa Kemal Ataturk inspired the Pakistani people in their fight for independence against the British. As an indication of the countries' ties, Ataturk's name has been given to a variety of institutes, libraries, and to the most beautiful districts in Pakistan's big cities. ${ }^{18}$ Turkey's historic relations with Pakistan gained momentum with the 1964 Agreement of Regional Cooperation for Development (RCD) that brought together Turkey, Iran, and Pakistan. ${ }^{19}$ The warm and friendly relations were further intensified in many respects in the aftermath of the military coup in Turkey on September 12, 1980. Military leaders of Turkey and Pakistan, namely President General
Kenan Evren and President General Zia ul-Haq, respectively, paid a series of visits to each other's country until the latter was killed in a plane crash on August 17, 1988. These ceremonial visits increased the magnitude of sympathy and of trade and cooperation in many fields, including civilian and military spheres. There was, therefore, fertile soil for rumors to grow. Hence, when NATO blocked Pakistan's enrichment program in early 1980s, President Zia ul-Haq reportedly opened talks with Turkey, taking advantage of his "brotherhood" with his Turkish counterpart Kenan Evren. At the same time, Greek Prime Minister Papandreou told U.S. Secretary of State Alexander Haig about Turkey's work on the nuclear bomb. Papandreou reportedly said that " $\mathrm{Pa}$ kistan expected Turkey to act as a transshipper of material for a nuclear bomb and would reciprocate by proudly sharing the nuclear bomb technology with Turkey."20

In 1982, TAEC was abolished and succeeded by the Turkish Atomic Energy Authority (TAEA). TAEA was established by law as a governmental organization under the direct supervision of the prime minister. ${ }^{21}$ In the fall of 1983, in order to reinvigorate the interrupted efforts, seven major suppliers were invited to submit bids to install nuclear power plants in Turkey. Eventually, letters of intent for the supply of three power reactors in two sites were issued to three firms: Atomic Energy of Canada, Ltd. (AECL) for a $655 \mathrm{MWe}$ CANDU reactor in Akkuyu; Kraftwerk Union (KWU) of Germany for a 990 MWe PWR in Akkuyu; and General Electric of the United States for one or two 1,185 MWe boiled water reactors in Sinop. 
The total cost of these three units was estimated to be $\$ 3.4$ billion. ${ }^{22}$

\section{Talks with Canadian and German Firms}

Preliminary results of the site surveys conducted in Sinop by an expert team dispatched by General Electric, as well as the team's consultations with experts from the IAEA and from Turkey, who had previously carried out similar studies in the region, concluded that a nuclear power plant was not feasible. They determined that, without conducting much more elaborate and comprehensive studies to assess the impact of the fault lines deep in the Black Sea basin on the probability of an earthquake in the region, no further steps could be taken to construct a nuclear site. Hence, negotiations with General Electric came to an end. However, negotiations with AECL and KWU continued throughout 1984 , and the parties agreed to several points for the preparation of contract documents and the financing schemes for a turnkey approach. At that time, the newly established government in Turkey suggested a so-called "builtoperate-transfer" (BOT) model for the supply of power reactors. The BOT model was launched with a view to attracting foreign investments to Turkey in many fields, and the nuclear deal was also considered in the same vein. With BOT, the Turkish government suggested that AECL and KWU construct the nuclear sites by forming joint venture utilities (JVU) with Turkey's TEK; operate the reactors for 15 years by selling the generated electricity to TEK; and then hand over their share in the nuclear site to TEK. Both AECL and KWU were also required to be responsible for a greater portion of financing of the power plants that they would build in the form of a JVU with TEK. ${ }^{23}$ While both firms agreed in principle to such a plan, KWU would later decline to undertake the supply of the reactor, reportedly due to a disagreement about the financing conditions imposed by the Turkish government. Hence, AECL was left as the sole potential supplier for all three reactors. On January 3, 1985, Turkey reportedly invited AECL to conduct final negotiations for the supply of reactors for its Akkuyu and Sinop nuclear units. ${ }^{24}$ The Canadian firm was said to have made serious attempts to find loan guarantees to finance the Akkuyu reactor and requested a $\$ 1$ billion loan guarantee both from the Canadian government and banks. ${ }^{25}$ However, negotiations with AECL ran into problems when the Canadian government failed to approve the plan. ${ }^{26}$ The Canadian government requested government guarantees from Turkey for the financing, and submitted a proposal containing a credit package and certain conditions. But, the Turkish government did not find the proposal consistent with the requirements of the BOT scheme, and the deal was suspended. ${ }^{27}$ Although the deal was declared to be terminated by the Turkish Minister of Energy Cahit Aral, an AECL official stated that his organization was still negotiating with Turkey for a contract to build and operate a CANDU reactor near Akkuyu. ${ }^{28}$ But, another AECL official apparently admitted that "it [was] not possible for an agreement to be reached within the framework of a build-own-run formula with the Turkish government."29 Yet, in January 1987, Prime Minister Turgut Ozal was quoted as saying that Turkey was ready to evaluate further proposals from AECL to go ahead with the reactor deal. ${ }^{30}$ And, in June 1987, it was reported that negotiations with AECL continued after the Canadian government failed to approve a plan for AECL to build the plant and run it for 15 years. It was also reported that talks with KWU were reopened. ${ }^{31}$

Nevertheless, none of these talks have come to fruition, not only because of financial problems, but also because of political considerations of the Canadian and German governments. The main reason behind the withdrawal of KWU from the deal was probably the reaction of the West German goverument to Turkey's improving relations with East Germany. Although such a view cannot be attributed to any official communication or document, it was perceived in Turkish diplomatic circles. With regard to the Canadian firm, it was reported that AECL had withdrawn its bid for a nuclear plant "in response to pressure from Western countries which [are] concerned that Turkey may build a nuclear bomb based on CANDU technology." 32 Opposition from Greece, Israel, and France resulted in a deadlock in efforts to procure financing for the project. ${ }^{33}$ Western countries feared that Turkey would do what Pakistan did-modify the technology to gain the capability to build an atomic bomb. ${ }^{34}$ Allegations increased especially in the aftermath of the interview of Abdel Qader Khan, a key figure in Pakistan's nuclear program, with an Indian journalist in March 1987. Thereafter, in a press conference held on October 28, 1987, Ambassador Inal Batu, then-spokesperson of the Turkish Ministry of Foreign Affairs, explicitly denied re- 
ports that Turkey would sell material for nuclear arms production to Pakistan. Ambassador Batu said that "Turkey fulfilled with great care its obligations under the NPT." 35

Later, Indian sources reported that the Indian government was looking over reports that Turkey was illegally selling nuclear weapons-related materials to Pakistan. Kapil Verma, a member of the Congress-I Party, was quoted as saying that "India should try to persuade the Turkish government to give up their strategic nuclear equipment." ${ }^{.36}$ In mid-1988, Leonard S. Spector, from the Carnegie Endowment for International Peace, reportedly indicated that "although the United States had put an end to the smuggling of sensitive material by Pakistan, both India and Pakistan had accumulated the nuclear materials necessary for bomb production." ${ }^{37}$ Building upon Spector's views, Indian authorities argued that "Turkey was used as an intermediary in many of Pakistan's clandestine activities," even though Spector did not cite any country's name. ${ }^{38}$

\section{Talks with Argentine Firms}

When talks with Canadian and German firms for the construction of nuclear power plants ran into trouble, Turkey sought other partners in the nuclear field. Hence, Turkey signed a 15-year nuclear cooperation agreement with Argentina on May 3, 1988. The agreement paved the way for potential transfers from Argentina of technical assistance, including front-end nuclear fuel cycle research and development; and research on power and research reactor planning, construction, quality assurance, operation, and regulation. IAEA safeguards would apply to all nuclear material designed for the use of nuclear technology to be transferred under the accord. Turkey and Argentina also agreed that safeguards on Argentine supplies would continue even if the agreement expired. At the same time, Turkey became interested in the 380 MWe Argos PWR design unveiled a year earlier by Empresa Nuclear Argentina de Centrales Electricas (ENACE). ${ }^{39}$ Argentina agreed to help Turkey study the feasibility of a site for Argos in Turkey. As part of this agreement, Turkish scientists and technicians would go to Argentina's Bariloche Nuclear Center for training. The two countries explored other areas for cooperation, including uranium mining, nuclear fuel plants, industrial production of radioisotopes, and safety requirements. ${ }^{40}$

Turkey also sought an agreement with Argentina for the construction of an Argentine-made $25 \mathrm{MWe}$ nuclear reactor, the CAREM-25, in Ankara. Professor Atilla Ozmen, then-director of TAEA, stated that "the offer [would] include financial help, as well as technical personnel." "4l The CAREM-25 reactor was developed by Investigaciones Aplicadas (INVAP) at Bariloche, to be fueled with four percent enriched uranium. During a visit in late April 1989, Professor Ozmen reportedly said that "Prime Minister Ozal [was] looking to follow the example of Argentina in achieving independence in certain high technology fields such as nuclear energy."'42 He said, "Turkish engineers, scientists and companies would fully participate in construction of the Argentine reactor, and the eventual purchase of the Argentine [Argos] reactor [would] also help ease power shortages in
Turkey forecast for the mid 1990s." ${ }^{43}$ Argentine officials were hopeful Turkey would buy a 380 MWe Argos PWR from ENACE, provided the CAREM-25 reactor project worked out well. ${ }^{44}$

In October 1990, Turkey and Argentina agreed to form a joint architect-engineering firm to develop Argentina's modular low power CAREM-25 reactor. Two Turkish firms, Sezai Turkes-Fevzi Akkaya (STFA) and TEK, and two Argentine firms, Comision Nacional de Energia Atomica, and INVAP formed the new firm. The agreement included a commitment to build two 25 MWe CAREM-25 units, one in each country. While Turkey agreed to provide most of financing for the work, Argentina agreed to provide most of the technology. Accordingly, Argentina would provide Nuclear Steam Supply System (NSSS) technology, basic and detailed engineering for the balance of plant, construction management, and regulatory expertise. If preparations for building of two units had gone ahead as planned, work on the first unit in Argentina would have begun in 1991, and construction of the second unit, in Turkey, would have begun in $1992 .{ }^{45}$ The long-term goal of the joint venture was to export the reactor to other nations in Latin America, Africa, and the Middle East. ${ }^{46}$ Turkish Prime Minister Turgut Ozal and the Argentine President Carlos Menem had corresponded and met regarding the project, and hence played a key role in obtaining agreement.

Despite the fact that elaborate and high-level talks in the nuclear field have been held between Argentina and Turkey and have culminated in a formal document, no progress has 
been made. Reportedly, Argentina's decision in the early 1980s to appoint Adolfo Saracho, a former head of Argentina's nuclear energy commission, the new Ambassador to Ankara, made "the United States, the Soviet Union, and German diplomatic missions in Buenos Aires uneasy." 47 When Turkey and Argentina agreed in October 1990 to set up a joint venture company to build CAREM-25 reactors in each country, "the United States, the Soviet Union, and Germany believed that Turkey's acquisition of nuclear technology would be disadvantageous." 48 Hence, the United States was said to have "worried because of the fears that Turkey might sell this technology to Pakistan."49 William Rope, first undersecretary at the U.S. embassy, has reportedly made several calls trying to determine how nuclear cooperation between Turkey and Argentina would affect other countries in the region, particularly Pakistan. ${ }^{50}$

Although the formal agreement for nuclear cooperation with Argentina is still in force, the CAREM-25 project was canceled a year later by a unilateral decision of executives at TAEA. Professor Yalcin Sanalan, then-director of TAEA, was especially influential in the decision. He notes that "[he] found the prospects of the CAREM-25 deal ambiguous" on the grounds that "CAREM-25 was too small for electricity generation and too big for research or training, however, very suitable for plutonium production" and thus a proliferation concern. Therefore, Professor Sanalan "concluded that such an ambiguous project would decrease the chances of Turkey in its current and future quest for largescale nuclear power plants which the country really needed." In Profes- sor Sanalan's words, "when TAEA declared that it unilaterally canceled the CAREM-25 project, [he] as the director of TAEA was then frequently invited to 'inner circle' meetings and dinners of the $\mathrm{OECD} /$ NEA." Professor Sanalan also notes that "the OECD countries then openly expressed in these meetings their wishes to help Turkey acquire nuclear power plants, provided the latter had well defined objectives in that area."sl By implication, the OECD countries prior to and after the unilateral cancellation of the CAREM-25 project by Turkey, were concerned about proliferation problems if Turkey acquired advanced nuclear technology and material.

\section{Third Phase: The 1990s}

Despite the concerns of Western nuclear supplier countries about Turkey's acquisition of nuclear power plants and thus advanced nuclear technology, Turkish experts continued to make estimates in the early 1990s of the amount of nuclear energy that Turkey will need in the next decades. Figures provided by experts indicate that, in order to meet Turkey's ever growing energy needs, a 1,000 MWe capacity per annum should become operational as of 2005. Total installed nuclear power capacity should reach $34,000 \mathrm{MWe}$ by 2040 . Experts came to this conclusion by considering both the estimated population growth rate and the yearly increase in energy consumption in Turkey during the first half of the 21 st century. Hence, an approximate and rather stable 5,000 (kWh) per capita consumption (based on a population of 110 million in the year 2040) will result in the need for 550 (TWh) energy by then. But, since total electricity production by domestic resources will barely attain the 320
TWh level, then the difference (i.e., $230 \mathrm{TWh}$ ) will have to be generated by relying on various non-domestic sources. Given that a 1,000 MWe nuclear reactor capacity can generate 6,750 MWh electricity per annum, operating on average at 70 percent productivity, then 34,000 MWe installed capacity would yield an estimated energy generation of $230 \mathrm{TWh}$ in $2040 .{ }^{52}$ Although the above scenario envisions a solution to Turkey's long-term energy needs, installation of some 35 large-scale nuclear power plants seems very unlikely, and not only because of technical or financial constraints. Fears of a Pakistani connection appear to still exist in 1997 linked to the fact that Pakistan reportedly succeeded in assembling one or more nuclear explosive devices in the early 1990 s, or will soon have the capability to do so. The disintegration of the Soviet Union and Turkey's intensified relations with the Turkic republics in Central Asia and Caucasus, some of which have nuclear installations, have only increased the West's concerns.

One of the most significant accusations regarding Turkey's alleged role in Pakistan's nuclear weapons program in the 1990s came from U.S. Senator John Glenn. In his article published in The Washington Post on June 24, 1992, Senator Glenn pointed to the history of the Reagan and Bush administrations in dealing with the issue of nuclear proliferation in regards to Pakistan. Senator John Glenn and Senator Stuart Symington had amended the Foreign Assistance Act in 1977 so that no country could receive U.S. aid if it imported or exported unsafeguarded nuclear enrichment or reprocessing materials or equipment. In 1979, U.S. aid to Pakistan was cut off for violations of this act. Senator Glenn 
claimed that "the credibility of the Bush and Reagan administrations' commitment to nuclear nonproliferation has been destroyed by their willful misinterpretation of the U.S. laws." $\$ 3$ He said "U.S. assistance allowed Pakistan to divert funds to its nuclear program, thus damaging the nuclear nonproliferation effort." $\$ 4$ In that context, Senator Glenn also mentioned the "failure of the GlennSymington amendment to stop aid to Turkey, because of its involvement in aiding Pakistan in its acquisition of uranium enrichment equipment."ss As a reaction to Senator Glenn's accusations, Turkish officials promptly denied that Turkey was supplying Pakistan with sensitive equipment used in the production of nuclear weapons. Also in 1992, U.S. congressmen reportedly accused Turkey of helping Pakistan with its nuclear program. ${ }^{56}$

A more recent concern about the possibility of a Turkish-Pakistani connection and Turkey's alleged nuclear weapons ambitions, came from Greece. Thanos Dokos from the Greek Foreign Ministry states that "[a]lthough Turkey does not possess the technological capability to develop nuclear weapons in the near future, Greece is worried about the alleged nuclear cooperation between Ankara and Islamabad, the rise of Islamic fundamentalism and (unconfirmed) reports that Turkey might try to acquire nuclear weapons material and technology and recruit nuclear scientists from the Muslim republics of the former Soviet Union." 57 Other sources in Greece have disseminated information to the same effect. For instance, a Greek daily, I Kathimerini, alleged that: "Turkey is attempting to acquire nuclear technology and nuclear warheads from the Islamic republics of the former Soviet Union, and is trying to acquire nuclear potential by cooperating with Pakistan in particular. The government of Greece is therefore deeply concerned by the development." Filiz Dincmen, then-spokeswoman of the Turkish Ministry of Foreign Affairs, said that "no efforts had been made to obtain raw materials or technology used in the manufacture of nuclear weapons from the former Soviet republics of Central Asia," and reiterated that "Turkey [was] a state party to the NPT and [had] fullscope safeguards agreement with the IAEA in force." $\$ 9$

Although, the veracity of these allegations is highly suspicious, ${ }^{60}$ their probable role in Turkey's failure to install nuclear power plants is worth serious consideration by the Turkish government if it hopes to avoid another backlash against initiatives to install such plants. Turkey's future energy production and consumption profiles indicate that peaceful exploitation of nuclear power may soon turn out to be a necessity for Turkey, although it should not be seen as a panacea.

\section{Turkey's Recent Initiative for Installing Nuclear Power Plants}

In early 1995 , it was reported that request for bids to construct a nuclear power plant at the Akkuyu site would be issued during the year. Later, the Turkish Electricity Generation and Transmission Company (TEAS) considered bids for a consultancy contract for the power plant project. TEAS was reported to have received bids from at least 14 consortia, including Turkish partner companies. In March 1995, the Korean Atomic Energy Research Institute (KAERI), with a consortium of
Korean companies and Turkish engineering firms, was said to be positioning itself as a contender in the upcoming bid to supply a nuclear plant to Turkey. KAERI had already begun work in Turkey in December 1994, along with Turkey's Gamb. ${ }^{61}$ KAERI won the contract to evaluate the nuclear development program drawn up by TEAS. The contract's main objectives included: investigation of internationally accepted contemporary nuclear power plant types and systems feasible for Turkey; review of bids solicited during previous attempts to set up a nuclear program in Turkey; and consultation with TEAS during bid evaluations and contract negotiations. ${ }^{62}$ KAERI examined the feasibility of renewing Turkey's project at Akkuyu. A review process was then scheduled for completion by mid-1996. A contractor will be selected by 1998 , with construction scheduled to begin in late 1998. Atomic Energy of Canada is expected to offer a $680 \mathrm{MWe}$ CANDU6 heavy water reactor, and Siemens of Germany is likely to offer a 1,400 MWe pressurized water reactor. ${ }^{63}$

According to the Turkish media, in December 1996, the Turkish government planned to accept bids for the nuclear plant to be built either as single unit with a capacity of 1,200 MWe or two equal units each with a capacity of $600 \mathrm{MWe}$. The cost of the plant is estimated to be about $\$ 1.5$ billion. However, because of recent political developments in Turkey that resulted in the so called pro-Islamic government coming to power, bidders were said to be reluctant to go ahead with the nuclear power plant deal. On January 20, 1997, at the request of the companies, Turkey extended the deadline for bidding which expired that day. ${ }^{64}$ Finally, the 
Minister of Energy Recai Kutan stated on April 28, 1997 that bidders will be announced on June 30 , $1997 . .^{65}$

\section{TECHNICAL \& POLITICAL PITFALLS OF NON- NUCLEAR ALTERNATIVES}

Turkey has learned little from its the past failures and has not taken measures to alleviate fears of Western nuclear supplier countries. Thus, Turkey's current attempt is likely to be another failure and a waste of time and resources. Why does Turkey still insist on installing nuclear power plants, particularly in light of beightened public awareness on nuclear and environmental issues in the aftermath of the Chernobyl disaster? Demonstrations against nuclear power plants have been staged sporadically both in big cities and the selected nuclear sites. Thus, conventional wisdom may suggest seeking alternative ways of generating electricity. There are, however, technical and political constraints on utilizing Turkey's other domestic sources of energy. There has not been a significant coordinated effort in Turkey to make use of geothermal, wind, or solar energy potential of the country. Full-fledge feasibility studies as to how to exploit these sources on a large-scale virtually do not exist. There has been plenty of rhetoric by successive government programs, but no concrete work has been accomplished. In addition, training a sufficient number of scientists, technicians, and administrators within the framework of master plans in these areas would take decades. ${ }^{66}$ Nevertheless, these alternatives should be studied.

There are political implications, along with the financial and techni- cal difficulties, if Turkey exploits its fresh water resources in its southern and eastern regions. ${ }^{67}$ Construction of dams on the Euphrates and Tigris rivers in southeastern Anatolia has always been a serious bone of contention between Turkey and its downstream neighbors, Syria and Iraq, as well as the Arab world. ${ }^{68}$ Formal declarations of the Arab League summits accuse Turkey of "using water as a weapon" against the Arabs. A clear indication of this can be seen in their objections to the construction of the large-scale Keban and Karakaya dams in the 1960 s and 1970s. Syria and Iraq have successfully lobbied in the Arab League in order to induce the latter to put pressure on international financial circles to block loans and assistance to Turkey's projects on the Euphrates and Tigris rivers. Hence, Ataturk dam, the fourth largest in the world, was constructed without any foreign financial or engineering aid. As a result, it has suffered from several delays and a considerable increases in total cost. ${ }^{69}$

Against this background, it becomes clear that unless Turkey installs nuclear power plants as an alternative primary source of energy, it will resort increasingly to foreign sources of energy such as imported oil and natural gas. Both of these commodities, however, are quite expensive as well as less reliable because their availability is highly dependent on several factors, including the nature of international politics. Turkey has been using Russian natural gas primarily for heating in heavily populated cities like Istanbul, Ankara, and Bursa. New projects are said to be underway to expand that network. However, as a result of the recently strained relations between the two countries, particularly over Chechen and Kurdish (PKK) issues, ${ }^{70}$ negotiations for the renewal of the agreement that would also double the amount delivered to Turkey have been stalled for a considerable period. The strain has also jeopardized the overall effectiveness of the agreement. ${ }^{71}$ Moreover, pipelines that will deliver natural gas and oil from Central Asia to the West appear highly unlikely to traverse Turkey because of the opposition of Russia, which is eager to host the pipelines. ${ }^{72}$ Hence, with a view to diversify its sources of energy, Turkey concluded a $\$ 20$ billion long-term natural gas agreement with Iran in August 1996. This new agreement prompted serious concerns in the West. The U.S. administration, in particular, considered such a move by the Turkish government as incompatible with its policy of containment of Iran, and asked Turkey not to go ahead with the deal. ${ }^{73}$

Therefore, because of the complex political implications of further exploitation of Turkey's fresh water resources or reliance on Russian and Iranian natural gas, nuclear power development prevails as a technically and economically feasible, as well as a politically more viable, alternative. Moreover, environmental experts consider nuclear energy to be cleaner than thermal energy generated by fossil fuels that cause carbon dioxide emissions. With regard to nuclear infra- and superstructure, TAEC/TAEA and TEK/TEAS have gone through a learning process over the past three decades during the deliberations for nuclear technology transfer. Likewise, Turkish scientists, technicians, and administrators have accumulated a good deal of knowledge and experience in the nuclear field, and conducted studies, among other issues, on recovery of uranium 
from various districts of the country. Design studies on uranium extractors and uranium dioxide (UO2) powder production, as well as the operation of a pilot plant, proved successful, and the first pilot plant started to operate in late 1986 with 1.5 ton uranium concentrate imported from Canada. ${ }^{74}$ Turkey's natural uranium and thorium deposits are said to be 8,400 tons and 380,000 tons, respectively, of which the former may constitute a basis for three $650 \mathrm{MWe}$ pressurized heavy water reactors. ${ }^{75}$ Thorium reserves may also be used for nuclear energy generation, provided the necessary technological steps are taken. All in all, a fertile soil exists in Turkey for peaceful exploitation of nuclear energy.

\section{CONCLUSIONS AND RECOMMENDATIONS}

If successful, nuclear power generation will still be expensive and dependent on foreign assistance in many respects. However, Turkey's partners will be mainly its long-term allies, such as the United States, Canada, Germany, France, and Belgium, as well as its emerging trade partners, such as Japan, South Korea, Argentina, and Brazil. The pace of relations is less likely be affected by irrational political moves if both sides take the measures necessary to ensure that there are neither possibilities for diversion of technologies to Pakistan nor avenues for unsubstantiated rumor-mongering.

The primary duty to take corrective steps certainly rests on the side of Turkey. First and the foremost, the Turkish government should commission comprehensive studies with a view to work out a master plan regarding: the possible role of nuclear energy in Turkey's overall energy needs; the country's uranium, thorium, and other nuclear-related natural resource reserves; the selection of nuclear reactor types; and the identification of sites for the reactors that will be needed in the decades to come. ${ }^{76}$ The master plan should be worked out fully using all of the necessary scientific and economic criteria. It should then be codified by law so as to make it immune to changes in the domestic political climate. The relevant cadres of scientists and technicians, whose institutes have been either abolished or hurt by bureaucratic transitions over the years, should again be gathered together and oriented towards a welldefined, civilian nuclear energy program. To complement this, Turkey should express its eagerness to accede to the Nuclear Suppliers Group and to abide by its guidelines by passing the necessary export control laws. ${ }^{77}$ These new laws could hurt Turkey's industrial exports. ${ }^{78} \mathrm{How}-$ ever, the benefits of the peaceful application of nuclear energy, such as plentiful and relatively cheap electricity, may offset these costs. Informed cadres in the nuclear field should take steps to create and then develop a proper nuclear culture in all respects (e.g., nuclear safety, nonproliferation, and environmental protection). Above all, Turkish politicians, public servants, and other officials must be briefed about international concerns pertaining especially to nuclear nonproliferation. Before putting the blarne on external actors for Turkey's difficulties to date in acquiring nuclear technology, Turkey must adopt the necessary domestic measures to silence those concerns.

As for the corrective actions suggested for the Western nuclear sup- plier countries, some new thinking should be applied regarding the treatment of Turkey. Western countries should assign a much higher priority to Turkey's energy requirements. They should consider the socio-political as well as the foreign policy implications of the possible deterioration of Turkey's economy in case of a serious energy crisis. Such a crisis might have unanticipated and unprecedented consequences not only for Turkey, but for the broader region. A few Turkish politicians have made irresponsible and reckless statements in the past that have added impetus to rumors about possible misuses of a would-be nuclear capability of Turkey. However, their significance should not be exaggerated. Turkey is a democratic country and, although they might be less developed than those in advanced countries in the West, checks and balances do exist. Moreover, Turkey, as a state party to the NPT, is and will be subject to the IAEA's scrutiny according to its obligations under the "full-scope" safeguards agreement in force since 1982. Furthermore, cadres of Turkish scientists, scholars, and technicians with solid backgrounds and advanced education in the fields of nuclear engineering and nuclear physics from the world's best institutes are well aware of the political implications of improper use of nuclear technologies. If these guidelines are followed by the relevant parties, thre should be no grounds for Turkey to be neglected by the West any longer. 
${ }^{1}$ This study is based in part on views expressed to the author, in personal interviews or via correspondence, by individuals from the Turkish state bureaucracy and academia (some of whom wish to remain anonymous). The anthor would like to express his deep gratitude to Professor Yalcin Sanalan, Head of the Nuclear Engineering Department, Hacettepe University, Ankara (former Director of Turkish Atomic Energy Authority, and Vice-Chairman of the Board of Governors of the International Atomic Energy Agency) for his invaluable contributions at every stage of this study. ${ }^{2}$ The guiding principle of Turkish foreign and security policy as laid down by Mustafa Kemal Ataturk, the founder and the first President of the Republic of Turkey, is "peace at home and peace in the world."

${ }^{3}$ For a comprehensive discussion on these matters, see Mustafa Kibaroglu, "Turkey," in Harald Muller, ed., Europe and Nuclear Disarmament (Frankfurt: Peace Research Institute Frankfurt PRIF, 1997), forthcoming.

4 Growth rate of population in Turkey is 2.1 percent per annum.

$s$ The overall installed capacity reached 21 gigawatts electric (GWe) by 1996, of which $10 \mathrm{GWe}$ came from hydroclectric, and $11 \mathrm{GWe}$ from thermal plants fueled with both domestic and imported coal, natural gas, and oil. In terms of electricity production, the total capacity reached 104 trillion watts hour (TWh) (hydro $36 \mathrm{TWh}$; thermal $68 \mathrm{TWh}$ ) with a net production of 84.5 TWh (hydro $32 \mathrm{TWh}$; thermal $52.5 \mathrm{Twh}$ ). Average productivity of hydroelectric plants is 88 percent, while productivity of plants fueled with coal, oil and natural gas is 78 percent in the average. Gross electricity production was 8.6 TWh in 1970; $25 \mathrm{TWh}$ in 1980; and $57 \mathrm{TWh}$ in 1990. There is an almost steady 15 percent loss in the electricity network due to a variety of reasons which rendered the net production figure available for consumption to 66 TWh in 1996. The net per capita electricity consumption is recorded to be 1050 kilowatts hour (kWh) in that year. Source: Lecture notes of Ozden Bilen, former Director of State Hydraulic Works (DSI) of Turkey, Hydropolitics and Strategical Research and Development Centre, Hacettepe University, Ankara, spring 1996.

6 Taking into consideration the seven percent increase per annum in electricity consumption along with a high population growth, demand for electricity is predicted to be $310 \mathrm{TWh}$ in the year 2010 . Turkey's main domestic energy sources, namely fresh water and coal have potentials of $125 \mathrm{TWh} /$ year and 105.TWh/y, respectively. Source: Lecture notes of Ozden Bilen.

${ }^{7}$ For an expert view on these matters, see Dogan Oner (Vice-Chairman of Turkish Atomic Energy Authority-TAEA), "Nukleer Guc Reaktorlerinde Teknoloji Transferi ve Uretimi" (Technology Transfer and Production in Nuclear Power Reactors), Uluslararasi Nukleer Teknoloji Kurultayi
(International Nuclear Technology Forum), October 12-15, 1993, Ankara Makine Muhendisleri Odasi (Chamber of Mechanical Engineers), Ankara, Publication No: 168 (March 1994), pp. 269-273.

The negative effect of the fear of especially the U.S. administrations of a Pakistani connection is confirmed by authorities from the Turkish Ministry of Foreign Affairs, and the Turkish Atomic Energy Authority. Moreover, Professor Steven Cohen, an expert on India's and Pakistan's nuclear programs at the University of Illinois, also confirmed the concerns of the U.S. administrations in that regard, and the possibility of a negative effect on Turkey's quest for nuclear power plants. Author's conversations with Professor Cohen during his visit to the Center for Nonproliferation Studies (CNS) at the Montercy Institute of International Studies, Monterey, California. March 24, 1997.

- CNRTC was founded on a 3,200 acres beside the Kucuk Cekmece lake in the outskirts of Istanbul. Nuclear research and training are being conducted in its 10 departments. See the website of the Turkish Atomic Energy Authority (TAEA) (http://www.nukleer.gov.tr).

${ }^{10}$ The number of staff in ANRTC currently is 161 , including 75 scientists, 36 technicians, and 50 administrative personnel. ANRTC began with 12 staff persons. See the website of TAEA (http:// www.nukleer.gov.tr).

II The intervention of the military in domestic politics, on March 12, 1971, with the so-called "Generals' Memorandum" resulted in drastic changes in the government. Turkey was then administered for a couple of years by a series of short-lived ministerial cabinets.

12 See Kenan Unlu, "Turks Take Steps to Revive Their Nuclear Programme," Nuclear Engineering International (January 1995), pp. 16-17.

${ }^{13} \mathrm{Jbid}$.

14 Ibid. Also see Ahmet Kutukcuoglu (former Director of Nuclear Power Plants Division of TEK), "Turkiye'nin Gecmisteki Nukleer Enerji Deneyimleri" (Past Experiences of Turkey in the Nuclear Field), Uluslararasi Nukleer Teknoloji Kurultayi (International Nuclear Technology Forum), October 12-15, 1993, Ankara Makine Muhendisleri Odasi (Chamber of Mechanical Engineers), Ankara, Publication No: 168 (March 1994), pp. 40-44.

is The third of the so-called once-every-tenyear intermissions in Turkish democracy took place on September 12, 1980 (previously on May 27, 1960 and March 12, 1971) as a result of the military coup of the then-Joint Chiefs of Staff. The democratic regime was re-established with the country-wide elections held in November 1983.

${ }^{16}$ Author's telephone conversation with Omer Ersun, Turkish ambassador to Ottawa, March 24, 1997.

${ }^{17} \mathrm{~A}$ very common belief in the public domain in Turkey can be translated as "there are no friends of Turks but the Turks" which is quickly followed up with "except the Pakistanis."
${ }^{18}$ The same applies to Pakistani leaders such as Mohammed Ali Cinnah and Zulfikar Ali Butto whose names have been given to institutes, libraries, and districts in Ankara and Istanbul. In March 1997, Humayun Han Banghash, the Pakistani ambassador to Ankara, confirmed this friendship during the reception of celebration of the 50th anniversary of the foundation of Pakistan. In his speech, Ambassador Banghash said "the Pakistani people have once more demonstrated how much they admire Ataturk [by hanging everywhere posters of Ataturk and Cinnah]." Hurriyet (Istanbul), March 21, 1997, p. 1.

${ }_{19}$ The $\mathrm{RCD}$ remained in existence until 1979. In 1985 , the RCD, by then dormant, was resuscitated as the Economic Cooperation Organization (ECO). After the disintegration of the Soviet Union, Turkey attempted to enlarge the ECO to include Azerbaijan, the Central Asian Republics, and Afghanistan. See the website of the Turkish Ministry of Foreign Affairs (http:// www.mfa.gov.tr).

${ }^{20}$ See "Turkey's Role in Pakistan's Nuclear Program," Worldwide Report, March 20, 1987, pp. 1-4. Source: CNS Nuclear Databases.

${ }^{21}$ The basic undertakings of TAEA are "to determine and progress the basis of the national policy and the related plans and programs and to submit them to be approved by the Prime Minister; to execute and to support scientific, technical and administrative studies; to give approval, permission and license to the nuclear installations; to enlighten the public in nuclear matters; to establish research and educate the personnel in the nuclear field." See Yalcin Sanalan, "Turkiye Atom Encrjisi Kurumu'nun Nukleer Enerji Uretimindeki Yeri" (The Role of TAEA in the Development Nuclear Energy), Uluslararasi Nukleer Teknoloji Kurultayi (International Nuclear Technology Forum), October 12-15, 1993, Ankara Makina Muhendisleri Odasi (Chamber of Mechanical Engineers), Ankara, Publication No: 168 (March 1994), pp. 128-134. ${ }^{22}$ See "The Chosen Three," Nuclear Engineering International (December 1983), p. 4.

${ }^{23}$ For a precise account on this matter, see Ahmet Kutukcuoglu, "Turkey's Joint Venture Scheme," Nuclear Engineering International (March 1986), p. 29.

24 "Turkey: AECL Close, KWU Still Running, WMHI Out," Nuclear News(February 1985), p. 102. ${ }^{25}$ Diane Francis, "Bank Risk Share Asked in Turkish Reactor Deal," The Toronto Star (Toronto), November 13, 1985, p. G1. Source: CNS Nuclear Databases.

26 "Candu Sales Hit Problems," Nuclear Engineering International (October 1986), p. 14.

${ }^{27}$ Kenan Unlu, "Turks Take Steps to Revive their Nuclear Programme," p. 16.

28 AECL's statement was made in response to a Reuter's report on Ostober 15, 1986, in which the Turkish Minister reportedly said that the deal was suspended. See "AECL Says That it is Still Negotiating With Turkey," Nuclear News (November 1986), p. 21.

${ }^{29}$ Ray Silver, "Atomic Energy of Canada, Ltd. 
(AECL) is not Conceding Either Turkish or Argentinian Prospects for CANDU Sales," Nucleonics Week, January 22, 1987, pp. 8-9. ${ }^{30} \mathrm{lbid}$.

31 "Still Negotiating," Nuclear Engineering International (June 1987), p. 38.

32 "Canadian Firm Drops Bid to Build Nuclear Plant," Nuclear Developments, February 25, 1988, p. 39. Source: CNS Nuclear Databases.

${ }^{33} \mathrm{lbid}$.

${ }^{34}$ Ibid.

$3 s$ "Spokesman Denies Nuclear Sales to Pakistan," Nuclear Developments, January 28, 1988, p. 95. Source: CNS Nuclear Databases.

36 "MP Notes Turkish Nuclear Equipment to Pakistan," Nuclear Developments, April 1, 1988, p. 5. Source: CNS Nuclear Databases.

37 "U.S. Expert Interviewed in South Asian Nuclear Arming," Nuclear Developments, September 2, 1988, pp. 17-19. Source: CNS Nuclear Databases.

38 Ibid.

${ }^{39}$ ENACE is 75 percent owned by Argentine Comision Nacional De Energia Atomica (CNEA) and 25 percent owned by KWU of Germany. See Richard Kessler, "Argentina Says Nuclear Accord With Turkey Sets Stage for Exports," Nucleonics Week, May 12, 1988, pp. 8-9.

40 "Argentina and U.S. in Co-operation Talks," Nuclear Engineering International November 1988),.p. 3.

"I "More Argentine Sales?" Nuclear Engineering International (July 1989), p. 5.

42 Richard Kessler, "Argentina Says Nuclcar Accord With Turkey ...," pp. 8-9.

${ }^{43} \mathrm{Ibid}$.

44 Ibid.

4s "Agreement Signed to Build Carem," Nuclear Engineering International (Deccmber 1990), p. 8. Also see Richard Kessler, "Argentina and Turkey to Form Nuclear A/E to Build a Small PWRs," Nucleonics Week, October 25, 1990, pp. 12-13. For more on this issue sec "Nuclear Pact With Argentina 'Secretly Signed'," Nuclear Developments, November 15, 1990, pp. 29-30. Source: CNS Nuclear Databases.

46 "Reactor Venture Entered With Turkey," Nuclear News (December 1990), p. 46.

"It was reported that Saracho made a significant contribution to the signing on May 3, 1988 of a nuclear technology cooperation agreement. Saracho was quoted as saying that "Argentina's objective [was] to help Turkey develop its nuclear technology without depending on any country or bloc, and hope[d] to help Turkey build reactors and nuclear power plants in the future." Sec "Argentina to Help Acquire "Nuclear Technology'," Nuclear Developments, June 21, 1988, p. 39. Source: CNS Nuclear Databases.

48 Ibid.

49 "Nuclear Pact With Argentina 'Secretly Signed"," Nuclear Developments, November 15, 1990, pp. 29-30. Source: CNS Nuclear Databases. 30 "'. Secret Talks' With Argentina on Nuclear Plant," Nuclear Developments, October 6, 1989, pp. 31-32. Source: CNS Nuclear Databascs.
51 Author's e-mail correspondences with Professor Yalcin Sanalan, Department of Nuclear Engineering, Hacettepe University, Ankara, February/March 1997.

${ }^{32}$ For details, see Dogan Oner (former Deputy Director of Turkish Atomic Energy Authority), "Turkiye'nin Nukleer Enerji Santralleri Konusunda Ileriye Donuk Politikalari Ne Olmalidir" (What Should be Turkey's Forward Looking Policies About Nuclear Power Plants?), Karayollari Vakfi Dergisi (Journal of Highway Foundation) (April 1991), p. 19.

53 John Glenn, "This Country Encouraged the Spread of Nuclear Weapons," The Washington Post, June 24, 1992, p. A19.

${ }^{54}$ Ibid.

ss Ibid.

56 "Turkey: Reports of Nuclear Transfer to Pakistan Denied," Proliferation Issues, July 10, 1992. p. 29. Source: CNS Nuclear Databases.

${ }^{57}$ Unlike many other Greek-origin publications, Dr. Thanos Dokos was kind enough to use the words "alleged" and "unconfirmed" regarding a Turkish-Pakistani connection. But still, the fear of such a connection apparently is keenly felt in Athens. Dr. Dokos expressed his views not in his official capacity but in a recent scholarly work. See, Thanos Dokos, "Greece," in Harald Muller, ed., Nuclear Export Controls in Europe (Brussels: European Interuniversity Press, 1995), p. 208.

${ }^{58}$ See I Kathimerini (Athens), December, 29, 1991, p. 1. Cited in "Turkey Reportedly Seeking Soviet Nuclear Warheads," Proliferation lssues, January 31, 1992, p. 61. Source: CNS Nuclear Databases.

39 "Ministry Denies Trying to Get Nuclear Technology," Proliferation Issues, January 31 , 1992, p. 67. Source: CNS Nuclear Databases. ${ }^{60}$ It is interesting but not surprising to note that, behind the allegations about a TurkishPakistani connection are, in most cases, sources from Greece and India, both of which are adversaries of one of the parties accused for being in illicit collaboration.

61 "Turkish Plant: Bids in 1995," Nuclear Engineering International (January 1995), pp. 6-7.

62 TEAS said KAERI's bid was the most comprehensive and, at $\$ 350,000$, the lowest it received. "Korea Prepares for Turkish Bid," Nuclear Engineering International (March 1995), p. 5.

${ }^{63}$ Mark Hibbs, "Turkey Expected to Request Bids for PWR Project in Coming Weeks," Nucleonics Week, March 21, 1996, pp. 1-2.

44 "Turkey Extends Nuclear Bid Enquiry Period," Anatolia News Agency (Ankara), January $21,1997$.

${ }^{65}$ Suna Erdem, "Turkey Signs \$13.5 Billion Deal With Gazprom," Reuter, April 28, 1997.

66 Importing expertise in these areas which are less controversial than nuclear technology can be a feasible short-term measure.

${ }^{67}$ Turkey has other fresh water resources in the Black Sea region. However, the mountainous topography of the region hardly allows construction of hydroelectric plants.

${ }^{68}$ Whereas Turkey suggests "allocation" of the waters of the Euphrates-Tigris river basin, total of 1,000 cubic meters per second $(\mathrm{m} 3 / \mathrm{sec})$ originating mainly (approximately 95 percent) from its territory, Syria and Iraq insist on a "sharing" agreement for at least a "guaranteed" $500 \mathrm{~m} 3 / \mathrm{sec}$ amount per country. For a scholarly assessment of the stance of the parties to the water dispute, as well as prospects for peaceful solutions that are rarely mentioned in international political sphere, see Aysegul Kibaroglu, "Prospects for Co-operation in the Euphrates-Tigris River Basin," in Peter Howsam and Richard C. Carter, eds., Water Policy: Allocation and Management in Practice (London: E \& FN Spon, 1996), pp. 31-38. For more comprehensive studies on this topic see John F. Kolars and William A. Mitchell, The Euphrates River and the Southeast Anatolia Development Project, Water: The Middle East Imperative (Carbondale: Southern Illinois University Press, 1991); Nurit Kliot, Water Resources and Conflict in the Middle East (London: Routledge Press, 1994); Thomas Naff and Ruth C. Matson, Water in the Middle East: Conflict or Cooperation? (Boulder, Colo.: Westview Press, 1984); Natasha Beschorner, "Water and Instability in the Middle East," Adelphi Paper, No. 273 (1993); Pritt J. Vesilind, "Water: the Middle East's Critical Resource," National Geographic (May 1993).

${ }^{69}$ The two downstream riparians followed a similar strategy against the $672 \mathrm{MW}$ Birecik dam project near Gaziantep on the Euphrates which will generate 2.5 TWh electricity. Moreover, the Iraqi embassy in Ankara gave a note to the Turkish Foreign Ministry on March 17, 1993, and Syria also gave a note to this effect to the Turkish embassy in Damascus on July 18, 1993. See, the website of Turkish Ministry of Foreign Affairs (http://www.mfa.gov.tr). Despite all contentious efforts, a consortium of firms from Turkey, Austria, Belgium, and France that undertook the construction of the dam has reportedly secured a $\$ 1.3$ billion syndicated loan from 44 banks of 10 countries signed in November 1995, after a decade of deliberations. See "Turkish BOT Projects Emerge Despite Political Uncertainties," International Trade Finance, January 19, 1996, via NewsNet (http://www.newsnet.com).

${ }^{7}$ For an account on this issue, see Robert Olson, "The Kurdish Question and Chechnya: Turkey versus Russia Since the Gulf War," Middle East Policy 4 (March 1996), pp. 106-118.

"Finally, on April 28,1997, Turkey signed a landmark agreement with Russia's gas giant Gazprom for \$13.5 billion worth of natural gas over 25 years, starting in 1997. Minister of Energy Recai Kutan told attendees at the signing ceremony that Turkey's gas need would shoot up to 27 billion cubic meters (bcm) annually by the year 2000 , and to $60 \mathrm{bcm}$ by 2010. See Suna Erdem, "Turkey Signs $\$ 13.5$ Billion Deal With Gazprom," Reuter, April $28,1997$.

${ }^{2}$ See Mustafa Kibaroglu, "Impact of the North- 
ern Tier on the Middle East: A Rejoinder," Security Dialogue 27 (September 1996), pp. 319-324.

${ }^{73}$ In May 1993, the Clinton administration adopted the policy of "dual containment" to isolate Iran together with Iraq from the world, as it did towards the latter for five years, in order to curb their ambitions to develop weapons of mass destruction. Accordingly, the United States uses its political weight to persuade Russia, China, and its Western allies to refrain from getting into relationships with these "rogue" states that would help them acquire the weapons-related know-how and economic power to enable them finance weapons programs. The U.S.-Iran confrontation has its roots in the "hostage crisis" in the U.S. embassy in Tehran in 1979. Iran's support of international terrorism and its efforts to revitalize the Bushehr nuclear reactors site with Russian assistance further exacerbated tensions.

74 See the website of TAEA (http:// www.nukleer.gov.tr).

${ }^{75}$ See Dogan Oner, "Turkiye'nin Nukleer Enerji Santralleri Konusunda Ileriye Donuk Politikalari Ne Olmalidir," pp. 18-24.

${ }^{76}$ Presumably KAERI is hired by TEAS to conduct such a study, at least in part. Turkish scientists, scholars, engineers, and technicians as well as politicians should become much more heavily involved in such studies.

$\pi$ Membership in the Nuclear Suppliers Group (NSG) requires a unanimous "yes" vote of its existing members, including Greece. Ironically, Greece may warmly welcome Turkey's application to NSG, unlike its robust opposition to Turkey's European Union membership.

${ }^{73}$ Export control laws cover a long list of dualuse materials which are used in civilian goods manufacturing. Restrictions (or at least delays caused by intrusive inspections) on the import or export of these materials may have uneconomic effects on the manufacturing process. 